\title{
Hetero-Diels-Alder reactions of hetaryl and aryl thioketones with acetylenic dienophiles
}

\author{
Grzegorz Mlostoń ${ }^{* 1}$, Paulina Grzelak ${ }^{1}$, Maciej Mikina², Anthony Linden ${ }^{3}$ \\ and Heinz Heimgartner ${ }^{*} 3$
}

\author{
Full Research Paper \\ Address: \\ ${ }^{1}$ Department of Organic and Applied Chemistry, University of Łódź, \\ Tamka 12, PL 91-403 Łódź, Poland, ${ }^{2}$ Center of Molecular and \\ Macromolecular Studies PAS, Sienkiewicza 112, PL 90-363 Łódź, \\ Poland and ${ }^{3}$ Department of Chemistry, University of Zürich, \\ Winterthurerstrasse 190, CH-8057 Zürich, Switzerland \\ Email: \\ Grzegorz Mlostoń* - gmloston@uni.lodz.pl; \\ Heinz Heimgartner* - heinz.heimgartner@chem.uzh.ch \\ ${ }^{*}$ Corresponding author \\ Keywords: \\ dimethyl acetylenedicarboxylate (DMAD); hetero-Diels-Alder \\ reactions; high pressure reactions; methyl propiolate; thioketones; \\ thiopyrans

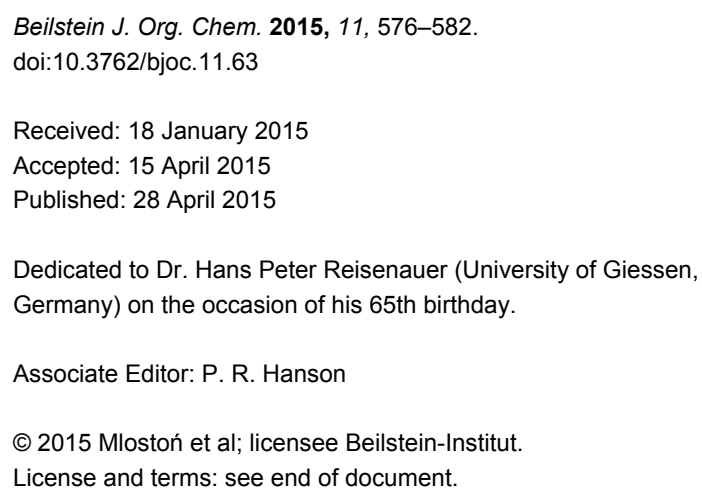

Open Access

\begin{abstract}
Selected hetaryl and aryl thioketones react with acetylenecarboxylates under thermal conditions in the presence of $\mathrm{LiClO}_{4}$ or, alternatively, under high-pressure conditions ( $5 \mathrm{kbar}$ ) at room temperature yielding thiopyran derivatives. The hetero-Diels-Alder reaction occurs in a chemo- and regioselective manner. The initially formed [4+2] cycloadducts rearrange via a 1,3-hydrogen shift sequence to give the final products. The latter were smoothly oxidized by treatment with $m$ CPBA to the corresponding sulfones.
\end{abstract}

\section{Introduction}

A series of recent publications evidence that, in contrast to earlier opinions, thioketones are useful building blocks for the preparation of diverse sulfur heterocycles [1-3]. Studies performed by Huisgen and coworkers are of special importance and they resulted in the formulation of the name 'superdipolarophiles' for aromatic thioketones [4-6]. In addition, Sauer and coworkers called them 'superdienophiles' based on kinetic studies [7,8]. Moreover, thiobenzophenone (1a) was reported to react as a heterodiene smoothly with cyclooctyne, dicyanoacetylene, and dimethyl acetylenedicarboxylate (2a) to give
$[4+2]$ cycloadducts of type $\mathbf{3 a}$, which spontaneously rearrange via a 1,3-hydrogen shift yielding rearomatized products of type 4a (Scheme 1) [9-11].

The same transformation occurred faster under photolytic conditions $[9,12]$. The hetero-Diels-Alder reaction of 4-substituted analogues of 1a with in situ generated benzyne is also known [13]. Heteroaromatic thioketones are reported to undergo a hetero-Diels-Alder reaction with dienophiles such as maleic anhydride, acrylonitrile, styrene, and $\alpha$-chloroacryloni- 
<smiles>COC(=O)C#CC(C)=O</smiles>

1a<smiles>COC(=O)C1=C(C(C)=O)C2(C=CC=CC2)C=CC=C1c1ccccc1</smiles>

3a<smiles>COC(=O)C1=C(C(=O)OC)c2ccccc2C(c2ccccc2)S1</smiles>

$4 a$

Scheme 1: Hetero-Diels-Alder reaction of thiobenzophenone (1a) with dimethyl acetylenedicarboxylate (2a) [10].

trile $[14,15]$. In the latter case, the stabilization of the initially formed cycloadduct occurred via $\mathrm{HCl}$ elimination, whereas, in the other cases, the 1,3-hydrogen shift led to rearomatized products.

In our ongoing studies on thioketones, we reported recently on selected reactions of new symmetrical and non-symmetrical hetaryl thioketones [16]. Among others, the reactions of $\mathbf{2 a}$ with phenyl thien-2-yl thioketone as well as with bis(thien-2-yl) thioketone were described. The goal of the present study is to examine the reactions of diverse hetaryl thioketones with both 2a and methyl propiolate (2b). Moreover, along with standard procedures, the high-pressure technique was applied. Finally, selected examples of the obtained polycyclic $2 \mathrm{H}$-thiopyrans were oxidized to give the corresponding sulfones.

\section{Results and Discussion}

Under standard conditions (benzene, rt), the reaction of $1 \mathbf{a}$ with $\mathbf{2 a}$ is slow, and it requires several days to be complete [9]. For that reason, we modified the procedure by using THF as a solvent and $\mathrm{LiClO}_{4}$ as a known, efficient catalyst applied frequently in diverse Diels-Alder reactions [17]. Heating the mixture in a closed tube to $50{ }^{\circ} \mathrm{C}$ resulted in completion of the reaction after only $24 \mathrm{~h}$, and after chromatographic work-up, the known product 4 a was obtained in $84 \%$ yield. Another attempt to optimize the reaction conditions was based on the use of the high-pressure method. This approach offers some advantages, especially in the case of cycloaddition reactions [18]. To the best of our knowledge, reactions of thioketones under highpressure conditions have never been studied. After a series of optimization experiments, a solution of $\mathbf{1 a}$ and $\mathbf{2 a}$ in a molar ratio of 1:2 in toluene was placed in a high-pressure vessel at $5 \mathrm{kbar}$, and after $24 \mathrm{~h}$ at room temperature, the product $\mathbf{4 a}$ was isolated in $70 \%$ yield.

The reaction conditions with THF and $\mathrm{LiClO}_{4}$ were used for further reactions of aryl thioketones, i.e., thiodibenzosuberone $\mathbf{1 b}$ and thiodibenzosuberenone 1c, with 2a. The expected polycyclic thiopyran derivatives $\mathbf{4 b}$ and $\mathbf{4 c}$, respectively, were obtained in 90 and $46 \%$ yield (Scheme 2 ). In the ${ }^{1} \mathrm{H}$ NMR spectra of both compounds the low-field shifted CHS signal appeared at 5.82 and $4.49 \mathrm{ppm}$. Finally, the $2 H$-thiopyran structure of $\mathbf{4 b}$ was established by X-ray single crystal structure determination (Figure 1).<smiles>S=C1c2ccccc2BOc2ccccc21</smiles><smiles>COC(=O)C#C[C+]C(C)C(=O)OC</smiles>

2a<smiles>COC(=O)C1=C(C(=O)OC)c2cccc3c2C(S1)c1ccccc1O3</smiles>

4b a-b $=\mathrm{CH}_{2}-\mathrm{CH}_{2}(90 \%)$ $4 c$ a $-\mathrm{b}=\mathrm{CH}=\mathrm{CH}(46 \%)$

1c $a-b=\mathrm{CH}=\mathrm{CH}$<smiles></smiles>

a) $\mathrm{THF}, \mathrm{LiClO}_{4}, 50^{\circ} \mathrm{C}$

b) toluene, $5 \mathrm{kbar}$, rt<smiles></smiles>

1d $X=\mathrm{MeN}$

1e $X=S$

$\begin{array}{ll}\text { 4d } X=\operatorname{MeN} & (35 \%,(a)) \\ \text { 4e } X=S & (35 \%,(b))\end{array}$ 


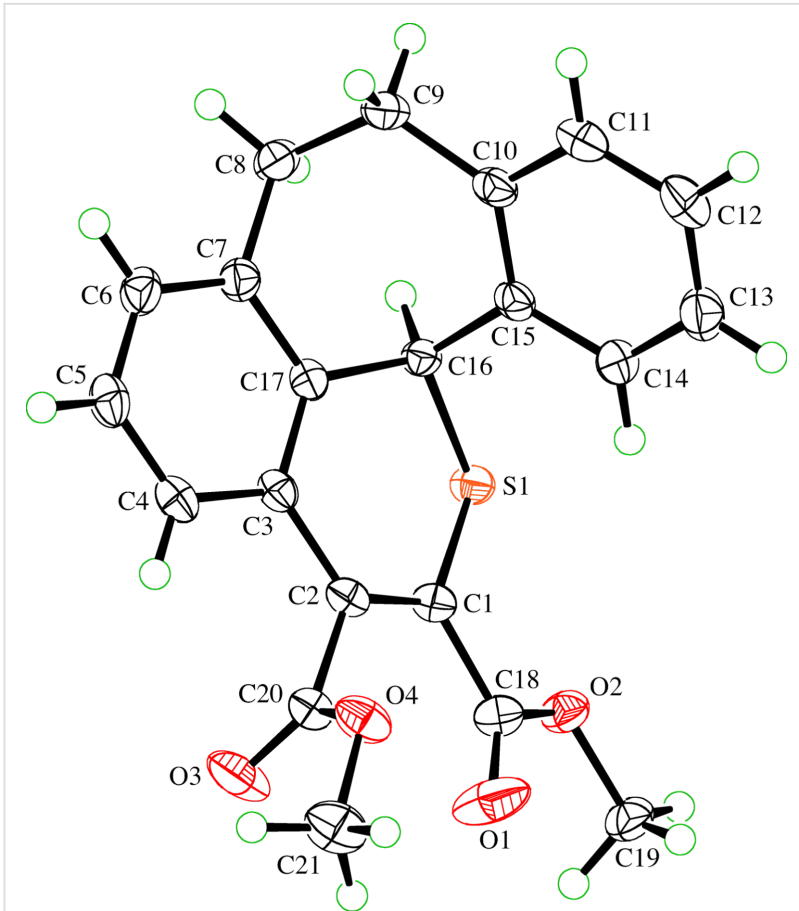

Figure 1: ORTEP Plot [19] of the molecular structure of $\mathbf{4 b}$, drawn using $50 \%$ probability displacement ellipsoids.

The analogous reactions of 2a with bis( $N$-methylpyrrol-2-yl) thioketone (1d) afforded the pyrrolo[2,3-c]thiopyran derivative 4d in modest yield (35\%) (Scheme 2). In the case of bis(thien2-yl) thioketone (1e), the reaction with $\mathbf{2 a}$ was carried out in toluene at room temperature under a pressure of $5 \mathrm{kbar}$. After $72 \mathrm{~h}$, the corresponding thieno[2,3-c] thiopyran $4 \mathrm{e}$ was obtained in $35 \%$ yield (Scheme 2 ).

In an extension of the study, reactions of methyl propiolate (2b) with selected aryl and hetaryl thioketones were performed under thermal and high-pressure conditions. The reaction of $\mathbf{1 a}$ with 2b in THF and a catalytic amount of $\mathrm{LiClO}_{4}$ led to the benzothiopyran 5a in $61 \%$ yield (Scheme 3 , Table 1 ). The ${ }^{1} \mathrm{H}$ NMR analysis of the crude mixture indicated the presence of a single regioisomer for which the structure $\mathbf{5 a}$ is proposed. In the alternative preparation of this product under high-pressure (toluene, 5 kbar), $66 \%$ of 5 a were isolated. Both methods were applied for analogous reactions with the symmetrical bis-hetaryl thioketones $\mathbf{1 e - g}$. Under thermal conditions, the products $\mathbf{5 d - f}$ were also formed regioselectively in 83,5 , and $6 \%$ yield, respectively. In these cases, the high-pressure experiments were also performed with 1e (16\% yield of 5d) and $\mathbf{1 f}$ (33\% yield of 5e), respectively; thioketone $\mathbf{1 g}$ was not tested under high pressure. However, attempted isolations of both $\mathbf{5 e}$ and $\mathbf{5 f}$ were unsuccessful as the products underwent decomposition upon chromatographic work-up. The experiment performed with the non-symmetrical phenyl thien-2-yl thioketone (1/h) under thermal conditions resulted also in the formation of a single product $\mathbf{5 g}$ in a chemo- and regioselective manner in $74 \%$ yield.

The experiment under high-pressure conditions was much less successful and gave $\mathbf{5 g}$ in only $17 \%$ yield. The structures of the products were determined based on the spectroscopic data. Thus, similar to hetero-Diels-Alder reactions with maleic anhydride [14], the $\mathrm{C}=\mathrm{C}$ bond of the thiophene ring of $\mathbf{1 h}$ is part of the reactive heterodiene system.

The reactions of $\mathbf{2 b}$ with thiobenzosuberone $\mathbf{1 b}$ and thiobenzosuberenone 1c were performed under thermal conditions, and in both cases, new polycyclic thiopyran derivatives $\mathbf{5 b}$ and $\mathbf{5 c}$, respectively, were formed regioselectively and obtained in good yields (94 and $61 \%$, respectively).

In order to test the scope and limitations of the heteroDiels-Alder reaction with thioketones and acetylenic dienophiles, other easily available acetylenes were used in the
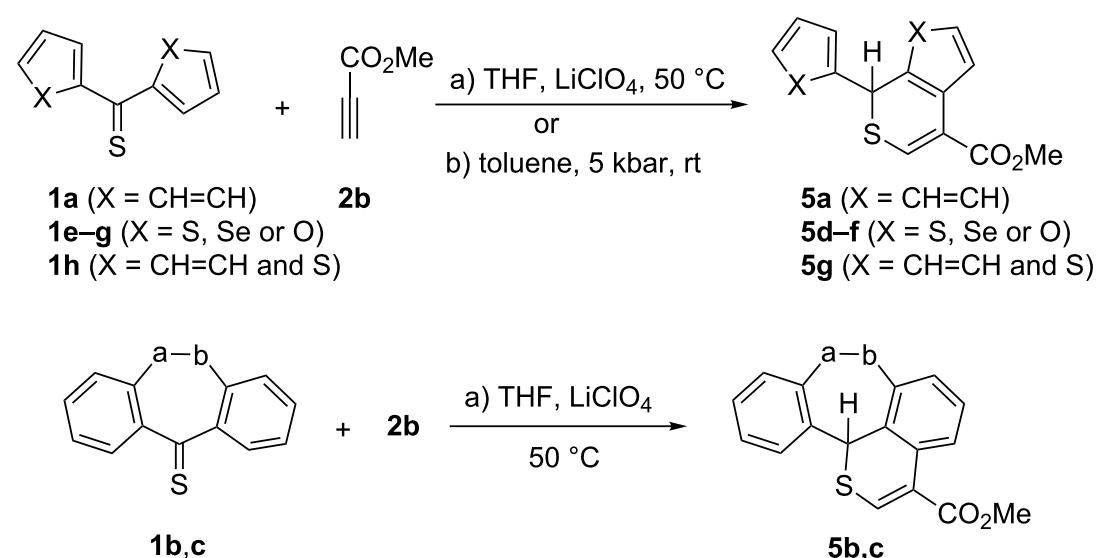


\begin{tabular}{|c|c|c|c|c|c|}
\hline 1 & $\mathrm{Ph} /$ Hetar & Hetar/Ph & 5 & $\begin{array}{c}\text { Method } A^{a} \\
\text { yield [\%] }\end{array}$ & $\begin{array}{c}\text { Method Ba } \\
\text { yield [\%] }\end{array}$ \\
\hline $\mathbf{a}$ & $\mathrm{Ph}$ & $\mathrm{Ph}$ & $\mathbf{a}$ & 61 & 66 \\
\hline b & & & b & 94 & - \\
\hline c & & & c & 61 & - \\
\hline e & thien-2-yl & thien-2-yl & d & 83 & 16 \\
\hline $\mathbf{f}$ & selenophen-2-yl & selenophen-2-yl & e & $5^{b}$ & $33^{c}$ \\
\hline $\mathbf{g}$ & furan-2-yl & furan-2-yl & $\mathbf{f}$ & $6^{b}$ & - \\
\hline h & $\mathrm{Ph}$ & thien-2-yl & $\mathbf{g}$ & 74 & 17 \\
\hline
\end{tabular}

${ }^{a}$ Methods A and B see Experimental; ${ }^{b}$ not isolated; ${ }^{c}$ decomposes during attempted chromatographic separation.

reaction with 1a. In all reactions attempted with phenylacetylene, (pyridin-2-yl)acetylene, and (tert-butyl)acetylene, no conversion of 1 a was observed as evidenced by the blue color of the reaction mixture even after $24 \mathrm{~h}$. Unfortunately, the experiments performed under the described conditions (THF, $\mathrm{LiClO}_{4}$, temp.) with (trifluoromethyl)acetylene and (diethoxyphosphoryl)acetylene, activated by the presence of strongly electron-withdrawing substituents, were also unsuccessful.

Some of the thiopyran derivatives $\mathbf{4}$ and $\mathbf{5}$ obtained in the present study were used for oxidation reactions aimed at the preparation of the corresponding sulfoxides and sulfones. As demonstrated in a recent publication [20], polycyclic sulfones are attractive substrates for the synthesis of polycyclic hydrocarbons via thermal $\mathrm{SO}_{2}$ extrusion. In our experiments, thiopyrans $\mathbf{4 a}, \mathbf{b}$ and $\mathbf{5 a}, \mathbf{b}$ were oxidized in $\mathrm{CH}_{2} \mathrm{Cl}_{2}$ solution at room temperature using 3.0 equivalents of $m \mathrm{CPBA}$. In the case of $\mathbf{4 a}$, the progress of the reaction was monitored by TLC and ${ }^{1} \mathrm{H}$ NMR spectroscopy. The spectrum recorded after $3 \mathrm{~h}$ showed that along with starting materials, two new products in a ratio of ca. 4:6 are present in the mixture. For that reason, the reaction time was extended to 3 days. Then, only one of these products was present, with characteristic signals of $2 \mathrm{MeO}$ groups at 3.93 and $4.05 \mathrm{ppm}$. The signal of the CHS group was shifted downfield and appeared at $5.48 \mathrm{ppm}$. The ESI mass spectra as well as the elemental analysis confirmed the molecular formula $\mathrm{C}_{19} \mathrm{H}_{16} \mathrm{SO}_{6}$, which corresponds with the structure of the sulfone 6a obtained in $90 \%$ yield (Scheme 4). Based on this result, the intermediate product observed in the mixture after $3 \mathrm{~h}$ can be proposed as the corresponding sulfoxide. No attempts were made to isolate this product.

The same oxidation protocol was applied to convert thiopyranes $\mathbf{5 a}, \mathbf{4 b}$, and $\mathbf{5 b}$ into the corresponding sulfones $\mathbf{6 b}-\mathbf{6 d}$ in 94,70 , and $80 \%$ yield, respectively. The structure of $\mathbf{6 d}$ was<smiles>[R]C1=C(C(=O)OC)c2ccccc2C(c2ccccc2)S1</smiles>

4a $\mathrm{R}=\mathrm{MeO}_{2} \mathrm{C}$

5a $\mathrm{R}=\mathrm{H}$<smiles>[R]C1=C(C(C)=O)c2ccccc2C(c2ccccc2)S1=O</smiles>

6a $\mathrm{R}=\mathrm{MeO}_{2} \mathrm{C}$

6b $\mathrm{R}=\mathrm{H}$<smiles>[R]C1=C(C(C)=O)c2cccc3c2C(S1)c1ccccc1CC3</smiles>

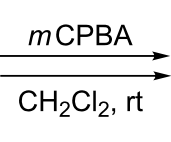<smiles>[R]C1=C(C(=O)OC)c2cccc3c2C2(c4ccccc4CC3)C1S2(=O)=O</smiles>

4b $\mathrm{R}=\mathrm{MeO}_{2} \mathrm{C}$

5b $\mathrm{R}=\mathrm{H}$

6c $\mathrm{R}=\mathrm{MeO}_{2} \mathrm{C}$

6d $\mathrm{R}=\mathrm{H}$ 
established by X-ray single crystal structure determination (Figure 2). The course of the oxidation reactions for these thiopyrans differs from a similar process reported for Se-containing systems. In these cases, ring contraction and elimination of an aryl group, but no formation of an oxidized product, was observed [21]. The same report describes the appearance of rearranged products (Pummerer-type rearrangement) upon treatment of 1H-2-benzothiopyran-3,4-dicarboxylates of type 4 with an equimolar amount of $m \mathrm{CPBA}$.

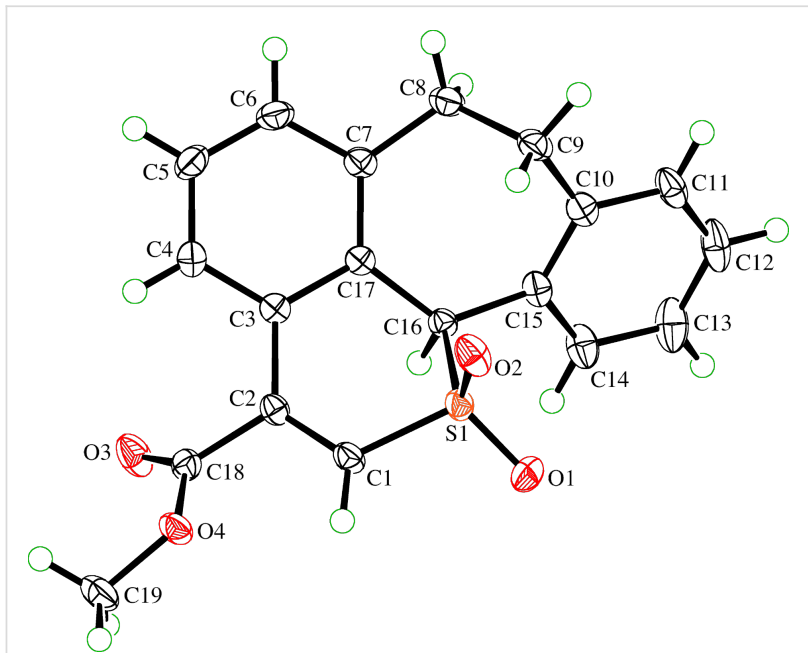

Figure 2: ORTEP Plot [19] of the molecular structure of one of the symmetry-independent molecules of $\mathbf{6 d}$, drawn using $50 \%$ probability displacement ellipsoids.

\section{Conclusion}

The present study shows that hetaryl thioketones react with activated acetylenecarboxylates in a hetero-Diels-Alder reaction followed by the 1,3-hydrogen shift to give fused thiopyran derivatives in a chemo- and regioselective manner. The thermal reaction can be catalyzed by $\mathrm{LiClO}_{4}$. Comparable reaction times were observed when the reaction was performed under high-pressure conditions at room temperature. The thiopyran derivatives can be oxidized by treatment with $m \mathrm{CPBA}$ at room temperature to give the corresponding sulfones. In this reaction, even when using equimolar amounts of $m \mathrm{CPBA}$, selective formation of the sulfoxide could not be achieved. The obtained sulfones are promising substrates for thermal $\mathrm{SO}_{2}$ extrusion reactions aimed at the contraction of the ring. The importance of the presented study is amplified by the fact that benzothiopyran and related systems containing a thiopyran moiety, and especially their carboxylic derivatives, are known as important pharmacophores, with key importance for the biological activity of diverse sulfur polyheterocycles [22-24].

It is worth of mentioning, that the described hetero-Diels-Alder reactions with aromatic thioketones as heterodienes, display certain similarities to the reported organometallic pathways observed in their reactions with triiron dodecacarbonyl $\mathrm{Fe}_{3}(\mathrm{CO})_{12}[25,26]$.

\section{Experimental}

General information: Melting points were determined in capillaries using a MEL-TEMP II apparatus (Aldrich) and are uncorrected. IR spectra were recorded with a FTIR NEXUS spectrophotometer as $\mathrm{KBr}$ pellets; absorptions $(v)$ in $\mathrm{cm}^{-1} .{ }^{1} \mathrm{H}$ and ${ }^{13} \mathrm{C}$ NMR spectra were measured on a Bruker Avance III $\left({ }^{1} \mathrm{H}\right.$ at 600 and ${ }^{13} \mathrm{C}$ at $150 \mathrm{MHz}$ ) instrument in $\mathrm{CDCl}_{3}$; chemical shifts $(\delta)$ are given in ppm, coupling constants $(J)$ in Hz. The multiplicity of the ${ }^{13} \mathrm{C}$ signals was deduced from DEPT, supported by ${ }^{1} \mathrm{H},{ }^{13} \mathrm{C}$ HMQC spectra. ${ }^{1} \mathrm{H}$ NMR data are presented as follows: chemical shift, multiplicity $(\mathrm{br}=$ broad, $\mathrm{s}=$ singlet, $\mathrm{d}=$ doublet, $\mathrm{t}=$ triplet, $\mathrm{q}=$ quartet, $\mathrm{m}=$ multiplet), coupling constant, integration. The mass spectra were recorded on a Finnigan MAT-95 (ESI), Bruker maxis (HRESI), or SYNAPT G2-S HMDS (HR MALDI-TOF) instrument. Elemental analyses were performed in the Microanalytical Laboraory of the Chemistry Faculty in Łódź. Reactions under high pressure were performed in a High Pressure Autoclave LC10T in the Laboratory of the Polish Academy of Sciences (CBMiM) in Łódź. Applied reagents such as DMAD, methyl propiolate, inorganic reagents, and solvents are commercially available (Aldrich) and were used as received.

Reaction of thioketones 1a-h with acetylenic dienophiles 2a or 2b - General procedures: Method A: A solution of $1 \mathrm{mmol}$ of the corresponding thioketone, $2 \mathrm{mmol}$ of the corresponding acetylenic dienophiles and $10 \mathrm{~mol} \%$ of $\mathrm{LiClO}_{4}$ in $1 \mathrm{~mL}$ of dry THF was placed in a thick-wall glass tube, which then was closed with a screw cap. The mixture was heated at $50{ }^{\circ} \mathrm{C}$ for $24 \mathrm{~h}$. The solvent was evaporated in vacuo. Subsequent separation on preparative plates coated with silica gel (eluent: $\mathrm{CH}_{2} \mathrm{Cl}_{2}$ ) gave pure products. Method B: The corresponding thioketone $(1 \mathrm{mmol})$ and acetylenic dienophile ( $2 \mathrm{mmol}$ ) were placed in a $4 \mathrm{~mL}$ teflon vial that was then filled with dry toluene. The vial was closed and kept at $5 \mathrm{kbar}$ at room temperature for $24 \mathrm{~h}$. After depressurizing, the solvent was removed in vacuo. Subsequent separation on preparative plates coated with silica gel (eluent: $\mathrm{CH}_{2} \mathrm{Cl}_{2}$ ) gave pure products.

Dimethyl 11,12-dihydro-4bH-benzo[4,5]cyclohepta[1,2,3ij]lisothiochromene-6,7-dicarboxylate (4b): Yield: $328.5 \mathrm{mg}$ (90\%). Colorless crystals; mp 147.5-148.0 ${ }^{\circ} \mathrm{C}(\mathrm{MeOH})$; IR (KBr) v: 3061 (w), $2948(\mathrm{w}), 1732$ (s), 1725 (s), $1597(\mathrm{w}), 1562$ (w), $1435(\mathrm{~m}), 1270(\mathrm{~s}), 1232$ (s), $1030(\mathrm{w}), 751(\mathrm{~m}) \mathrm{cm}^{-1}$; ${ }^{1} \mathrm{H}$ NMR $\left(600 \mathrm{MHz}, \mathrm{CDCl}_{3}\right) \delta 7.61\left(\mathrm{~d}, J=12 \mathrm{~Hz}, 1 \mathrm{H}_{\text {arom }}\right)$, 7.33-7.30 (m, 1 $\left.\mathrm{H}_{\text {arom }}\right), 7.24-7.15\left(\mathrm{~m}, 4 \mathrm{H}_{\text {arom }}\right), 7.03$ (d, $J=$ $6 \mathrm{~Hz}, 1 \mathrm{H}_{\text {arom }}$ ), 5.82 (br s, S-CH), 3.92, $3.94\left(2 \mathrm{~s}, 6 \mathrm{H}, 2 \mathrm{OCH}_{3}\right)$, 
3.55 (br s, 1CH), 3.37 (br s, 1CH), 3.12 (br s, 1CH), 3.01-2.97 (m, 1CH) ppm; ${ }^{13} \mathrm{C}$ NMR $\left(150 \mathrm{MHz}, \mathrm{CDCl}_{3}\right) \delta 168.1,164.3(2$ $\mathrm{C}=\mathrm{O}), 138.1,138.0,131.8,130.6\left(7 \mathrm{C}\left(\mathrm{sp}^{2}\right)\right), 136.3,128.0$, $127.5,126.4,125.3$ ( $\left.7 \mathrm{CH}_{\text {arom }}\right), 53.1,52.8\left(2 \mathrm{OCH}_{3}\right), 33.0$ (S-CH), 32.0 (broad, $2 \mathrm{CH}_{2}$ ) ppm; HRMS (ESI): $[\mathrm{M}+\mathrm{Na}]^{+}$ calcd for $\mathrm{C}_{21} \mathrm{H}_{18} \mathrm{NaO}_{4} \mathrm{~S}, 389.08180$; found, 389.08178; anal. calcd for $\mathrm{C}_{21} \mathrm{H}_{18} \mathrm{O}_{4} \mathrm{~S}$ : C, 68.82; H, 4.95; S, 8.75; found: $\mathrm{C}$, 68.71; H, 5.06; S, 8.82.

Dimethyl 4bH-benzo[4,5]cyclohepta[1,2,3-ij]isothiochromene-6,7-dicarboxylate (4c): Yield: $83 \mathrm{mg}$ (46\%). Orange solid; $\mathrm{mp} 139.7-140.0{ }^{\circ} \mathrm{C}$ (purified chromatographically); IR (KBr) v: 3018 (w), 2947 (w), 1728 (s), 1725 (s), 1596 (w), $1563(\mathrm{w}), 1433(\mathrm{w}), 1264(\mathrm{~s}), 1229(\mathrm{~s}), 1097(\mathrm{w}), 771(\mathrm{w})$ $\mathrm{cm}^{-1} ;{ }^{1} \mathrm{H}$ NMR $\left(600 \mathrm{MHz}, \mathrm{CDCl}_{3}\right) \delta 7.77(\mathrm{~d}, J=6 \mathrm{~Hz}$, $\left.1 \mathrm{H}_{\text {arom }}\right), 7.49-7.45\left(\mathrm{~m}, 2 \mathrm{H}_{\text {arom }}\right), 7.42\left(\mathrm{~d}, J=6 \mathrm{~Hz}, 1 \mathrm{H}_{\text {arom }}\right)$, $7.36\left(\mathrm{~d}, J=6 \mathrm{~Hz}, 1 \mathrm{H}_{\text {arom }}\right), 7.30,7.27(2 \mathrm{~d}, J=6 \mathrm{~Hz}, 2$ olefinic $\mathrm{HC}=), 7.23$ (d, $\left.J=6 \mathrm{~Hz}, 2 \mathrm{H}_{\text {arom }}\right), 4.49$ (s, S-CH), 3.92, 4.00 (2 $\left.\mathrm{s}, 6 \mathrm{H}, 2 \mathrm{OCH}_{3}\right) \mathrm{ppm} ;{ }^{13} \mathrm{C} \mathrm{NMR}\left(150 \mathrm{MHz}, \mathrm{CDCl}_{3}\right) \delta 167.8$, $164.2(2 \mathrm{C}=\mathrm{O}), 139.9,135.8,134.6,132.5,130.3,128.8,124.2$ $\left(7 \mathrm{C}\left(\mathrm{sp}^{2}\right)\right), 132.2,130.1,129.3,127.8,127.6,126.7,126.7$, 126.6, $125.2\left(7 \mathrm{CH}_{\text {arom }}+2 \mathrm{CH}_{\text {olefin }}\right), 53.2,52.8\left(2 \mathrm{OCH}_{3}\right), 41.8$ (S-CH) ppm; HRMS (MALDI-TOF): $[\mathrm{M}+\mathrm{Na}]^{+}$calcd for $\mathrm{C}_{21} \mathrm{H}_{16} \mathrm{NaO}_{4} \mathrm{~S}$, 387.0668; found, 387.0667 .

Methyl 11,12-dihydro-4bH-benzo[4,5]cyclohepta[1,2,3ij]isothiochromene-7-carboxylate (5b): Yield: $288.5 \mathrm{mg}$ (94\%). Yellow solid; mp 116.0-116.5 ${ }^{\circ} \mathrm{C}$ (chromatographic purification); IR (KBr) v: 3059 (w), 2946 (w), 1702 (s), 1591 (w), 1431 (w), 1221 (s), 1068 (m), 756 (m) cm ${ }^{-1} ;{ }^{1} \mathrm{H}$ NMR $\left(600 \mathrm{MHz}, \mathrm{CDCl}_{3}\right) \delta 7.93-7.87\left(\mathrm{~m}, 1 \mathrm{H}_{\text {arom }}\right), 7.84-7.80(\mathrm{~m}$, $\left.1 \mathrm{H}_{\text {arom }}\right), 7.61$ (br s, S-CH=), 7.28-7.23 (m, 2H arom), 7.21-7.17 (m, $2 \mathrm{H}_{\text {arom }}$ ), 7.03 (br s, $1 \mathrm{H}_{\text {arom }}$ ), 5.79 (br s, S-CH), 3.87 (s, 3H, $\mathrm{OCH}_{3}$ ), 3.55 (br s, $\left.1 \mathrm{CH}\right), 3.35$ (br s, $\left.1 \mathrm{CH}\right), 3.15$ (br s, $\left.1 \mathrm{CH}\right)$, 3.03-2.95 (m, 1CH) ppm; ${ }^{13} \mathrm{C}$ NMR $\left(150 \mathrm{MHz}, \mathrm{CDCl}_{3}\right) \delta$ $165.3(\mathrm{C}=\mathrm{O}), 142.0,138.7,137.6,135.2,125.7,125.4(6$ $\left.\mathrm{C}\left(\mathrm{sp}^{2}\right)\right), 132.4,130.6,129.3,128.0,127.8,127.1,126.6,126.1$ $\left(7 \mathrm{CH}_{\text {arom }}+\mathrm{S}-\mathrm{CH}=\right), 51.9\left(\mathrm{OCH}_{3}\right), 35.0(\mathrm{~S}-\mathrm{CH}), 32.2$ (broad, 2 $\mathrm{CH}_{2}$ ) ppm; HRMS (MALDI-TOF): $[\mathrm{M}+\mathrm{Na}]^{+}$calcd for $\mathrm{C}_{19} \mathrm{H}_{16} \mathrm{NaO}_{2} \mathrm{~S}$, 331.0761; found, 331.0769.

\section{Methyl 4bH-benzo[4,5]cyclohepta[1,2,3-ij] isothiochromene-} 7-carboxylate (5c): Yield: $85 \mathrm{mg}(61 \%)$. Yellow solid; $\mathrm{mp}$ 77.5-78.0 ${ }^{\circ} \mathrm{C}$ (chromatographic purification); IR (KBr) v: 3057 (w), 2948 (w), 1709 (s), 1644 (m), 1589 (w), 1432 (w), 1235 (s), $1066(\mathrm{~m}), 726(\mathrm{~m}) \mathrm{cm}^{-1} ;{ }^{1} \mathrm{H} \mathrm{NMR}\left(600 \mathrm{MHz}, \mathrm{CDCl}_{3}\right) \delta$ $7.98\left(\mathrm{~m}, 1 \mathrm{H}_{\text {arom }}\right), 7.95\left(\mathrm{~d}, J=6 \mathrm{~Hz}, 1 \mathrm{H}_{\text {arom }}\right), 7.75(\mathrm{~d}, J=12 \mathrm{~Hz}$, $\left.1 \mathrm{H}_{\text {arom }}\right), 7.43-7.41$ (m, $\left.1 \mathrm{H}_{\text {arom }}\right), 7.37-7.34\left(\mathrm{~m}, 2 \mathrm{H}_{\text {arom }}\right), 7.27$ (s, 1H $\left.\mathrm{H}_{\text {arom }}\right), 7.28-7.24\left(\mathrm{~m}, 1 \mathrm{H}_{\text {arom }}\right), 7.22,7.18(2 \mathrm{~d}, J=12 \mathrm{~Hz}, 2$ olefinic $\mathrm{HC}=), 4.45(\mathrm{~s}, \mathrm{~S}-\mathrm{CH}), 3.86\left(\mathrm{~s}, 3 \mathrm{H}, \mathrm{OCH}_{3}\right) \mathrm{ppm}$; ${ }^{13} \mathrm{C}$ NMR $\left(150 \mathrm{MHz}, \mathrm{CDCl}_{3}\right) \delta 165.2(\mathrm{C}=\mathrm{O}), 139.7,134.9$, $134.7,131.6,131.1,125.0\left(6 \mathrm{C}\left(\mathrm{sp}^{2}\right)\right), 138.7,131.9,131.6$, $130.7,130.2,128.8,127.9,127.8,126.5,126.1\left(7 \mathrm{CH}_{\text {arom }}+2\right.$ $\left.\mathrm{CH}_{\text {olefin }}+\mathrm{S}-\mathrm{CH}=\right), 51.9\left(\mathrm{OCH}_{3}\right), 41.3(\mathrm{~S}-\mathrm{CH}) \mathrm{ppm}$; MS (ESI) $m / z(\%): 207\left(100,[\mathrm{M}-74]^{+}\right), 245\left(55,[\mathrm{M}-36]^{+}\right), 297$ (45, $\left.[\mathrm{M}-16]^{+}\right)$; anal. calcd for $\mathrm{C}_{19} \mathrm{H}_{14} \mathrm{O}_{2} \mathrm{~S}: \mathrm{C}, 74.48 ; \mathrm{H}, 4.61 ; \mathrm{S}$, 10.46; found: C, 74.53; H, 4.99; S, 10.64 .

General procedure for the oxidation of thiopyran derivatives $4 \mathbf{a}, \mathbf{b}$ and $5 \mathbf{a}, \mathbf{b}$ : A solution of $1 \mathrm{mmol}$ of the corresponding thiopyran and $3 \mathrm{mmol}$ of $m \mathrm{CPBA}$ (70\% purity) in dichloromethane was stirred at room temperature for 3 days. Then the reaction mixture was extracted with aqueous saturated $\mathrm{NaHCO}_{3}(3 \times 10 \mathrm{~mL})$ and distilled water $(1 \times 10 \mathrm{~mL})$. The organic phase was dried over anhydrous $\mathrm{MgSO}_{4}$ and concentrated in vacuo.

Methyl 11,12-dihydro-4bH-benzo[4,5]cyclohepta[1,2,3ij]isothiochromene-7-carboxylate 5,5-dioxide (6d): Yield: $88 \mathrm{mg}(80 \%)$. Colorless crystals; $\mathrm{mp} 187.5-188.0{ }^{\circ} \mathrm{C}(\mathrm{MeOH})$; IR (KBr) v: 3041 (w), 2950 (w), 1717 (s), 1600 (w), 1433 (w), 1307 (s), 1262 (s), 1130 (s), 785 (m) cm ${ }^{-1} ;{ }^{1} \mathrm{H} \mathrm{NMR} \mathrm{(600} \mathrm{MHz,}$ $\left.\mathrm{CDCl}_{3}\right) \delta 7.60-7.48\left(\mathrm{~m}, 1 \mathrm{H}_{\text {arom }}\right), 7.36$ (br s, $\left.1 \mathrm{H}_{\text {arom }}+\mathrm{S}-\mathrm{CH}=\right)$, $7.32-7.28\left(\mathrm{~m}, 2 \mathrm{H}_{\text {arom }}\right), 7.27-7.20\left(\mathrm{~m}, 3 \mathrm{H}_{\text {arom }}\right), 5.72$ (br s $\mathrm{S}-\mathrm{CH}), 3.96$ (s, 3H, $\left.\mathrm{OCH}_{3}\right), 3.58$ (br s, $\left.1 \mathrm{H}\right), 3.10$ (br s, 2H), 2.91 (br s, 1H) ppm; ${ }^{13} \mathrm{C}$ NMR $\left(150 \mathrm{MHz}, \mathrm{CDCl}_{3}\right) \delta 164.9$ $(\mathrm{C}=\mathrm{O}), 134.5,134.3,132.2,131.0,130.8,129.2\left(6 \mathrm{C}\left(\mathrm{sp}^{2}\right)\right)$, $134.1,133.3,130.0,129.7,129.1,128.0,127.5,126.1$ (7 $\left.\mathrm{CH}_{\text {arom }}+\mathrm{S}-\mathrm{CH}=\right), 62.5\left(\mathrm{OCH}_{3}\right), 53.4(\mathrm{~S}-\mathrm{CH}), 37.3,34.7$ (2 broad signals, $2 \mathrm{CH}_{2}$ ) ppm; HRMS (ESI): $[\mathrm{M}+\mathrm{Na}]^{+}$calcd for $\mathrm{C}_{19} \mathrm{H}_{16} \mathrm{NaO}_{4} \mathrm{~S}, 363.06615$; found, 363.06614 .

\section{Supporting Information}

\section{Supporting Information File 1}

Experimental data for selected compounds 4-6, details of the crystal structure determination, and the original ${ }^{1} \mathrm{H}$ and ${ }^{13} \mathrm{C}$ NMR spectra for all products. CCDC-1038599 and 1038600 contain the supplementary crystallographic data for this paper. These data can be obtained free of charge from The Cambridge Crystallographic Data Centre via http://www.ccdc.cam.ac.uk/data_request/cif.

[http://www.beilstein-journals.org/bjoc/content/ supplementary/1860-5397-11-63-S1.pdf]

\section{Acknowledgements}

The authors thank the National Science Center (Cracow, Poland) for generous financial support (Grant Maestro-3 (Dec2012/06/A/ST5/00219). Skilful performance of microanalyses by Ms Hanna Jatczak and Ms Agnieszka Cieślińska (University of Łódź) is gratefully acknowledged. 


\section{References}

1. Mlostoń, G.; Heimgartner, H. In Targets in Heterocyclic Systems; Chemistry and Properties; Attanasi, O. A.; Spinelli, D., Eds.; Italian Society of Chemistry: Rome, 2005; Vol. 9, pp 141-157.

2. Mlostoń, G.; Heimgartner, H. In Targets in Heterocyclic Systems; Chemistry and Properties; Attanasi, O. A.; Spinelli, D., Eds.; Italian Society of Chemistry: Rome, 2006; Vol. 10, pp 266-300.

3. Okuma, K. Sulfur Rep. 2002, 23, 209-241. doi:10.1080/01961770208047971

4. Huisgen, R.; Fisera, L.; Giera, H.; Sustmann, R. J. Am. Chem. Soc. 1995, 117, 9671-9678. doi:10.1021/ja00143a008

5. Huisgen, R.; Langhals, E. Heteroat. Chem. 2006, 17, 433-442. doi:10.1002/hc.20262

6. Huisgen, R.; Li, X.; Giera, H.; Langhals, E. Helv. Chim. Acta 2001, 84, 981-999. doi:10.1002/1522-2675(20010516)84:5<981::AID-HLCA981>3.0.CO;2$\mathrm{O}$

7. Schatz, J.; Sauer, J. Tetrahedron Lett. 1994, 35, 4767-4770. doi:10.1016/S0040-4039(00)76962-0

8. Rohr, U.; Schatz, J.; Sauer, J. Eur. J. Org. Chem. 1998, 2875-2883. doi:10.1002/(SICI)1099-0690(199812)1998:12<2875::AID-EJOC2875> 3.0.CO;2-N

9. Gotthardt, H.; Nieberl, S. Liebigs Ann. Chem. 1980, 867-872. doi:10.1002/jlac.198019800607

10. Rapp, J.; Huisgen, R. Tetrahedron 1997, 53, 961-970 doi:10.1016/S0040-4020(96)01069-1

11. Huisgen, R.; Rapp, J. Heterocycles 1997, 45, 507-525. doi:10.3987/COM-96-7706

12. Ohno, A.; Koizumi, T.; Ohnishi, Y. Bull. Chem. Soc. Jpn. 1971, 44, 2511-2515. doi:10.1246/bcsj.44.2511

13. Okuma, K.; Yamamoto, T.; Shirokawa, T.; Kitamura, T.; Fujiwara, Y. Tetrahedron Lett. 1996, 37, 8883-8886. doi:10.1016/S0040-4039(96)02074-6

14. Ohmura, H.; Motoki, S. Bull. Chem. Soc. Jpn. 1984, 57, 1131-1137. doi:10.1246/bcsj.57.1131

15. Saito, T.; Shizuta, T.; Kikuchi, H.; Nakagawa, J.; Hirotsu, K.; Ohmura, H.; Motoki, S. Synthesis 1994, 727-732. doi:10.1055/s-1994-25558

16. Mlostoń, G.; Urbaniak, K.; Gębicki, K.; Grzelak, P.; Heimgartner, H. Heteroat. Chem. 2014, 25, 548-555. doi:10.1002/hc.21191

17. Fringuelli, F.; Taticchi, A., Eds. The Diels-Alder Reaction; Selected Practical Methods; J. Wiley \& Sons Ltd.: Chichester, U.K., 2002.

18. Matsumoto, M.; Hamana, H.; lida, H. Helv. Chim. Acta 2005, 88, 2033-2234. doi:10.1002/hlca.200590156

19. Johnson, C. K. ORTEP II, Report ORNL-5138; Oak Ridge National Laboratory: Oak Ridge, Tennessee, 1976.

20. Aitken, R. A.; Hauduc, C.; Hossain, M. S.; McHale, E.; Schwan, A. L.; Slawin, A. M. Z.; Stewart, C. A. Aust. J. Chem. 2014, 67, 1288-1295. doi:10.1071/CH14155

21. Okuma, K.; Kojima, K.; Koga, Y.; Shioji, K. Heterocycles 2000, 52, 1021-1024. doi:10.3987/COM-99-S118

22. Kaminskyy, D.; Kryshchyshyn, A.; Nektegayev, I.; Vasylenko, O.; Grellier, P.; Lesyk, R. Eur. J. Med. Chem. 2014, 75, 57-66. doi:10.1016/j.ejmech.2014.01.028

23. Tavakolinia, F.; Baghipour, T.; Hossaini, Z.; Zareyee, D.; Khalilzadeh, M. A.; Rajabi, M. Nucleic Acid Ther. 2012, 22, 265-270. doi:10.1089/nat.2012.0346

24. Rajabi, M.; Khalilzadeh, M. A.; Mehrzad, J. DNA Cell Biol. 2012, 31 , 128-134. doi:10.1089/dna.2011.1291
25. Daraosheh, A. Q.; Görls, H.; El-khateeb, M.; Mlostoń, G.; Weigand, W. Eur. J. Inorg. Chem. 2011, 349-355. doi:10.1002/ejic.201000770

26. Daraosheh, A. Q.; Apfel, U.-P.; Görls, H.; Friebe, C.; Schubert, U.-S.; El-khateeb, M.; Mlostoń, G.; Weigand, W. Eur. J. Inorg. Chem. 2012, 318-326. doi:10.1002/ejic.201101032

\section{License and Terms}

This is an Open Access article under the terms of the Creative Commons Attribution License

(http://creativecommons.org/licenses/by/2.0), which permits unrestricted use, distribution, and reproduction in any medium, provided the original work is properly cited.

The license is subject to the Beilstein Journal of Organic Chemistry terms and conditions:

(http://www.beilstein-journals.org/bjoc)

The definitive version of this article is the electronic one which can be found at: doi:10.3762/bjoc. 11.63 